\title{
6. ORGANIC GEOCHEMISTRY OF SEDIMENTS FROM THE ANGOLA BASIN AND THE WALVIS RIDGE: A SYNTHESIS OF STUDIES FROM DEEP SEA DRILLING PROJECT LEG 75 $^{1}$
}

\author{
Philip A. Meyers, Oceanography Program, Department of Atmospheric and Oceanic Science, The University of \\ Michigan, Ann Arbor, Michigan
}

\begin{abstract}
The results of organic geochemical studies of samples from Site 530 in the Angola Basin and from Site 532 on the Walvis Ridge are reviewed and integrated with sedimentological data from these sites. Sediments rich in organic matter accumulated during two periods at Site 530 . Black shales containing as much as $16.5 \%$ organic carbon were deposited in late Albian to early Santonian times, and organic-rich sediments were again laid down during the late Miocene through the Pleistocene. The appearance of the latter deposits coincides with the onset of high productivity associated with the Benguela Current, and these deposits may have originally accumulated on the Walvis Ridge, where sediments of a similar age and composition are found at Site 532. The high concentrations of organic matter reflect increased production and enhanced preservation of marine materials at both sites during these periods by combinations of rapid burial and poorly oxygenated, but not permanently anoxic, bottom conditions. Terrigenous contributions are evident but small. Organic matter in these sediments is immature throughout both sections.
\end{abstract}

\section{INTRODUCTION}

The organic-matter contents of oceanic sediments can be used to infer a number of paleoceanographic factors. Among these are changes over time in sedimenttransport processes, in surface-water productivity, and in the degree of oxygenation of bottom waters. In addition, the components of sedimentary organic matter undergo diagenetic change at varying rates, thus providing information about how extensively the original character of deposited organic materials has been altered by microbial, geochemical, and thermal processes.

The approach used in this overview of the organic geochemical studies conducted on sediments and rocks collected during Deep Sea Drilling Project (DSDP) Leg 75 has been to address a number of areas of geochemical and paleoenvironmental importance:

1) Where did the organic matter originate-in marine or terrigenous sources?

2) What depositional processes were active-for example, bioturbation, lateral transport by turbidity currents?

3) To what extent has the organic matter been preserved-and by.what conditions: anoxic bottom waters or rapid burial-or not been preserved?

4) What paleoceanographic changes can be detected from the interplay of source, deposition, and preservation?

5) How much thermal alteration of the organic matter has occurred?

6) Has any migration of organic-matter components or catagenetic products occurred?

The data and interpretations given in the organic geochemical reports published in this volume are discussed and integrated in terms of these questions.

${ }^{1}$ Hay, W. W., Sibuet, J.-C., et al., Init. Repts. DSDP, 75: Washington (U.S. Govt. Printing Office).
There are three limitations to the interpretations of the available geochemical information. First, most of the reported analyses are from core sections that were chosen on board Glomar Challenger specifically for organic geochemical investigation. These frozen samples may not be fully representative of the lithologic units from which they originated. Second, investigators received samples from different parts of each frozen core section. Lithologic differences between various subsamples may lead to different results among various investigators. Third, investigators generally chose to examine different sets of samples which were selected to satisfy their specific objectives. This synthesis attempts to minimize the effects of these several types of sampling bias.

The overview is in two main parts which combine the several holes sampled at the two sites occupied during DSDP Leg 75. Both parts are divided on the basis of the various lithologic units encountered at each site.

\section{SITE 530-ANGOLA BASIN}

Site 530 is located in the southeastern corner of the Angola Basin at a water depth of $4629 \mathrm{~m}$ and is about $20 \mathrm{~km}$ north of the eastern portion of the Walvis Ridge escarpment (Fig. 1). It is on the abyssal floor of the Angola Basin and is underlain by a stratigraphic sequence representative of the entire basin (Hay et al., 1982). Rotary drilling in Hole 530A provided sediments and sedimentary rocks from $115 \mathrm{~m}$ sub-bottom to basement at $1103 \mathrm{~m}$. Hydraulic piston coring (HPC) in Hole 530B gave sediments from the water/sediment interface to $181 \mathrm{~m}$ sub-bottom. Eight sedimentary units were found at Site 530. These units and the results of organic geochemical analyses of their samples are summarized in Table 1.

\section{Unit 1-Holocene to Early Pleistocene}

The sediment in stratigraphic Unit 1 consists of mixtures of nannofossils, diatoms, and clay with debris- 


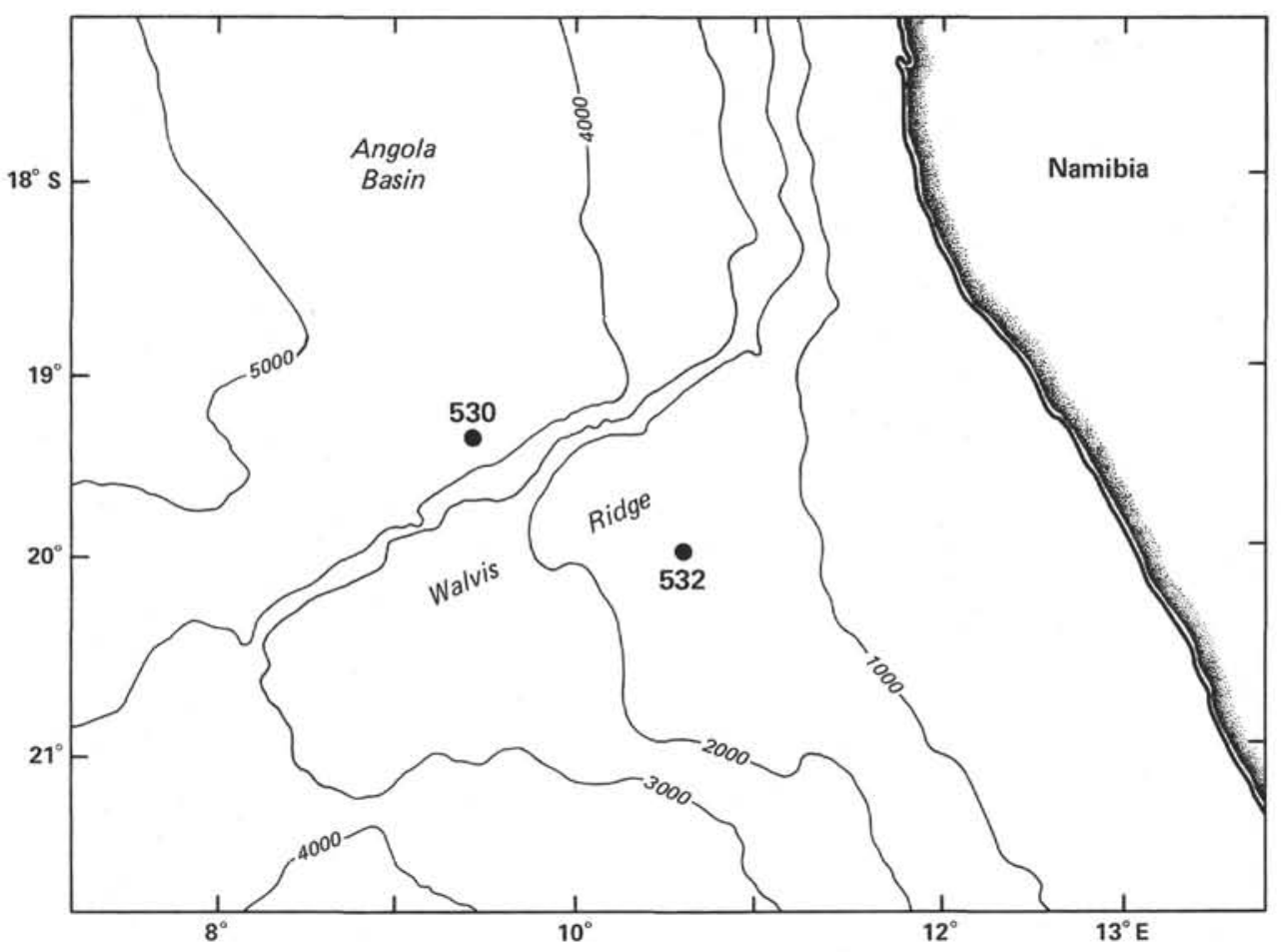

Figure 1. Locations of Site 530 in the Angola Basin and Site 532 on the Walvis Ridge. (Depth contours in m.)

flow deposits and turbidites interbedded into a background of bioturbated pelagic deposition. The thickness of this unit is $110 \mathrm{~m}$, and relatively undisturbed cores from the entire unit were obtained by HPC at Hole 530B. Two subunits were defined on the basis of relative abundances of diatoms and nannofossils. Subunit 1a consists of $58 \mathrm{~m}$ of Holocene and upper Pleistocene sediment rich in both diatoms and nannofossils; Subunit $1 \mathrm{~b}$ extends from $58 \mathrm{~m}$ sub-bottom to $110 \mathrm{~m}$ and is made up of diatom-rich, carbonate-poor sediments deposited in early Pleistocene times. The sedimentation rate of the entire unit averages $65 \mathrm{~m} / \mathrm{m}$.y. Hay et al., (1982) conclude that the origin of the debris-flow and turbidite materials in Unit 1 is from the Walvis Ridge and is related to the high surface productivity associated with the Benguela Current.

Geolipid analyses by Meyers and Dunham (this volume) of Pleistocene samples from both subunits yield distributions of $n$-alkanoic acids and $n$-alkanols which contain large amounts of long-chain components of landplant origin. Although an unresolved complex mixture of branched and cyclic aliphatic hydrocarbons suggestive of microbial reworking is present in the sediments, the respective odd versus even chain-length preference found in biological lipids is well preserved in the respective geolipid fractions. Pristane-to-phytane ratios are generally one or greater and indicate oxygenated or suboxic bottom waters during deposition of these sediments (Didyk et al., 1978). Similarities in geolipid contents between these Pleistocene sediments and a Pleistocene sediment from Site 532 support the conclusion that the debris-flow and turbidite deposits originated from similar environments on the Walvis Ridge.
Organic carbon concentrations of Unit 1 sediments average $3.2 \%$, about ten times higher than the DSDP average of $0.3 \%$ reported by McIver (1975) and of $0.2 \%$ for modern pelagic sediments (Degens and Mopper, 1976). The high organic carbon contents correlate with biogenic sediment components and reflect the high surface productivity in waters along the Namibian shelf. Up to $10 \%$ of the organic matter produced in upwelling zones can escape remineralization during sinking and become incorporated into underlying sediments, whereas only $1 \%$ or $2 \%$ reaches the ocean bottom under low productivity areas (Bishop et al., 1978). The observation that organic matter remains at high concentrations despite debris-flow and turbidite relocation indicates that reburial must have been rapid at this Angola Basin location.

Although no kerogen analyses were done on Unit 1 samples, the atomic $\mathrm{C} / \mathrm{N}$ ratios reported by Meyers, Brassell, and Huc (this volume) provide some indication of the character of the bulk organic matter in these sediments. The $\mathrm{C} / \mathrm{N}$ values in subunits $1 \mathrm{a}$ and $1 \mathrm{~b}$ are 13.3 and 13.1 , respectively. Because modern marine sediments have $\mathrm{C} / \mathrm{N}$ ratios in the range of 9 to 18 (Stevenson and Cheng, 1972; Müller, 1977), the Unit 1 values suggest that marine sources contribute much of the organic matter in these Holocene to Pleistocene sediments. Diagenesis can alter $\mathrm{C} / \mathrm{N}$ ratios, however, and hence their reliability as source indicators is limited and becomes less with age.

Considerable fluctuation in organic carbon concentrations occurs in Unit 1 sediments. The values range from 0.8 to $6.4 \%$ and can differ by as much as $2.5 \%$ in samples within a few meters of each other (Meyers, 
Brassell, and Huc, this volume). Atomic $\mathrm{C} / \mathrm{N}$ values vary little throughout this unit and suggest minor diagenetic alteration of organic matter after burial, because diagenesis has been shown to affect $\mathrm{C} / \mathrm{N}$ ratios in DSDP samples (Waples and Sloan, 1980). Hence, the variability in organic-carbon concentrations appears to record variations in inputs of organic matter having a nonchanging origin and may reflect processes which controlled sedimentation on the Walvis Ridge.

\section{Unit 2-Early Pleistocene to Late Miocene}

Calcareous biogenic sediments interbedded with thick debris-flow deposits and thin mud turbidites constitute stratigraphic Unit 2. The frequency and thickness of the debris-flow deposits decreases from the top to the bottom of this $167-\mathrm{m}$-thick unit. Their origin is believed to be from shallower locations on the Walvis Ridge (Hay et al., 1982) and in common with the debris flows in Unit 1. An average sedimentation rate of $20 \mathrm{~m} / \mathrm{m}$.y. is found in Unit 2.

Concentrations of organic carbon vary between 0.3 to $2.6 \%$ in this unit and average $1.4 \%$ (Meyers, Brassell, and Huc, this volume). The lowest values are found in upper Miocene sediments. The change from organiccarbon-lean pelagic sediments near the bottom of this unit to relocated biogenic sediments richer in organic matter in the upper part is evidently related to the onset and strengthening of the cold-water Benguela Current and the associated upwelling areas along the southwestern African coast. Based upon microfossils from Site 362 of DSDP Leg 40, Diester-Haass and Schrader (1979) and Siesser (1980) conclude that surface productivity first increased and planktonic communities shifted from warm-water to cold-water types in this part of the southeastern Atlantic during late Miocene times. The common appearance of debris-flow deposits and turbidites in the Angola Basin after this time indicates large accumulations of organic-carbon-rich biogenic sediment at shallower locations on the Walvis Ridge as a result of upwelling.

Analysis of lipids and kerogen contained in Unit 2 sediments shows both to be mixtures of marine and terrigenous materials (Rullkotter et al., this volume). Nonaromatic hydrocarbon distributions have large contributions of $n-\mathrm{C}_{29}, n-\mathrm{C}_{31}$, and $n-\mathrm{C}_{33}$ alkanes, which are characteristic of land plants (Simoneit, 1978a), and the most abundant component is the $\mathrm{C}_{31} n$-alkane. The presence of small amounts of $17 \mathrm{~B}(\mathrm{H})$-hopanes indicates partial microbial reworking of organic matter (Ourisson et al., 1979).

Aromatic hydrocarbon fractions contain alkylated thiophenes as major constituents, plus significant amounts of perylene (Rullkötter et al., this volume). As suggested by Simoneit et al. (1982) for DSDP Leg 64 sediments, the simultaneous presence of such sulfur compounds and of perylene may be diagnostic of anoxic conditions, either in near-bottom waters or in surficial sediments. The lack of preservation of shorter-chain $n$-alkanes characteristic of marine organisms, however, indicates that anoxic conditions could not have been well-developed and perhaps may have existed as an oxy- gen minimum zone which intermittently extended to the ocean bottom on the Walvis Ridge. Alternatively, marine lipid components may have been selectively degraded as a result of the downslope redistribution of sediments common in Unit 2.

Rullkötter et al. (this volume) characterize sediment kerogen by Rock Eval pyrolysis and by maceral microscopy. In Unit 2, type III kerogen dominates and indicates partly to strongly oxidized organic matter. Organic matter macerals are dominated by humic and liptinite matter derived from land plants. These authors conclude that terrigenous materials constitute 70 to $80 \%$ of the total organic matter in these sediments and that the relatively high organic matter concentrations (Table 1) are due to enhanced preservation from rapid burial by turbidites.

Little thermal alteration has occurred to the organic matter contained in these sediments. Distributions of $n$-alkanes retain their biogenic odd-over-even predominance, hydrogen index values are low, and vitrinite reflectance values are about 0.3 (Rullkotter et al., this volume). In addition, gaseous hydrocarbons are made up almost entirely of methane (see Jasper et al., this volume) and give no evidence of catagenetic hydrocarbon production.

\section{Units 3 Through 7-Late Miocene to Early Santonian}

Because nearly all of the sediments and rocks sampled in Units 3 through 7 are poor in organic carbon, these units are grouped together in this synthesis of their organic geochemistry. Few analyses were done on any of these units.

Unit 3 consists of green and red muds containing very thin distal turbidites and pelagic clay. The unit was deposited from the Oligocene to the late Miocene at an average sedimentation rate of $7 \mathrm{~m} / \mathrm{m}$.y. (Hay et al., 1982).

Unit 4 is made up of green mudstone with occasional interbeds of red mudstone, marlstone, nannofossil chalk, and clastic limestone. It was deposited at a rate of $5 \mathrm{~m} / \mathrm{m}$.y. during Maestrichtian to Eocene times. Bioturbated turbidites exist frequently in this unit.

Unit 5 contains Campanian through Maestrichtian mudstones, marlstones, and clastic limestones and sandstones. Turbidites are common to this unit and may have been deposited as part of a submarine fan. Sedimentation rates were variable but averaged $18 \mathrm{~m} / \mathrm{m} . \mathrm{y}$.

Volcanogenic sandstones of Campanian age compose Unit 6 . The sandstones occur as graded turbidites that accumulated at an average rate of $16 \mathrm{~m} / \mathrm{m}$.y.

The dominant lithology of Unit 7 is red claystone with interbeds of green and purple claystone, siltstone, and sandstone in numerous turbidite sequences. This unit accumulated at an average rate of $22 \mathrm{~m} / \mathrm{m}$.y. during the early Campanian to early Santonian. Near the base of this unit, a thin layer of black claystone was found.

Organic-carbon concentrations of samples from these units fall between 0.1 and $0.5 \%$, with the important exception of two samples from the early Santonian black 
Table 1. Inferred sources of organic matter from sediments in lithologic units from Holes 530 and 530B in the Angola Basin. Dominant source appears first. Lithologic information from Hay et al. (1982).

\begin{tabular}{|c|c|c|c|c|c|c|c|c|}
\hline \multirow[b]{2}{*}{ Unit } & \multirow[b]{2}{*}{ Lithology } & \multirow{2}{*}{$\begin{array}{l}\text { Sub-bottom } \\
\text { depth }(m)\end{array}$} & \multirow[b]{2}{*}{ Age } & \multirow{2}{*}{$\begin{array}{l}\text { Mean } C_{\text {org }} \\
(\%)^{\mathrm{a}}\end{array}$} & \multicolumn{3}{|c|}{ Inferred sources of organic matter } & \multirow{2}{*}{$\begin{array}{l}\text { Reference } \\
\text { (this volume) }\end{array}$} \\
\hline & & & & & Interstitial gases & Lipids & Kerogen & \\
\hline 1 & $\begin{array}{l}\text { Diatom nannofossil } \\
\text { marl and ooze }\end{array}$ & $0-110$ & $\begin{array}{l}\text { Holocene to } \\
\text { Pleistocene }\end{array}$ & 3.2 & & Terrigenous/marine & Marine/terrigenous & $\begin{array}{l}\text { Meyers and Dunham } \\
\text { Meyers, Brassell, and Huc }\end{array}$ \\
\hline 2 & $\begin{array}{l}\text { Nannofossil clay, marl, } \\
\text { and ooze }\end{array}$ & $110-277$ & $\begin{array}{l}\text { Pleistocene to } \\
\text { late Miocene }\end{array}$ & 1.4 & Biogenic & Terrigenous/marine & Terrigenous/marine & $\begin{array}{l}\text { Rullkötter et al. } \\
\text { Jasper et al. }\end{array}$ \\
\hline 3 & Red and green mud & $277-467$ & $\begin{array}{l}\text { late Miocene to } \\
\text { Oligocene }\end{array}$ & 0.3 & & & Marine & Meyers, Brassell, and Huc \\
\hline 4 & $\begin{array}{l}\text { Mudstone, marlstone, } \\
\text { chalk, and lime- } \\
\text { stone }\end{array}$ & $467-600$ & $\begin{array}{l}\text { Eocene to Maes- } \\
\text { trichtian }\end{array}$ & 0.3 & & & Marine & Meyers, Brassell, and Huc \\
\hline 5 & $\begin{array}{l}\text { Dark green mudstone, } \\
\text { marlstone, lime- } \\
\text { stone, and sand- } \\
\text { stone }\end{array}$ & $600-790$ & $\begin{array}{l}\text { Maestrichtian to } \\
\text { Campanian }\end{array}$ & 0.2 & Thermogenic & & Marine & $\begin{array}{l}\text { Meyers, Brassell, and Huc } \\
\text { Jasper et al. }\end{array}$ \\
\hline 6 & $\begin{array}{l}\text { Vulcanogenic sand- } \\
\text { stone }\end{array}$ & $790-831$ & early Campanian & 0.3 & & & Marine/terrigenous & Meyers, Brassell, and Huc \\
\hline 7 & $\begin{array}{l}\text { Red, green, and purple } \\
\text { claystone, siltstone, } \\
\text { and sandstone }\end{array}$ & $831-940$ & $\begin{array}{l}\text { early Campanian } \\
\text { to early San- } \\
\text { tonian }\end{array}$ & 0.6 & & & Marine/terrigenous & Meyers, Brassell, and Huc \\
\hline \multirow[t]{7}{*}{8} & $\begin{array}{l}\text { Red and green clay- } \\
\text { stone interbedded }\end{array}$ & $940-1103$ & $\begin{array}{l}\text { early Santonian } \\
\text { to late Albian }\end{array}$ & $\begin{array}{l}0.4 \\
\text { (claystones) }\end{array}$ & & Terrigenous/marine & & Brassell \\
\hline & with black shale & & & $\begin{array}{l}5.4 \\
\text { (shales) }\end{array}$ & & & Marine/terrigenous & Deroo et al. \\
\hline & & & & & & Terrigenous/marine & & Meyers, Trull, and Kawka \\
\hline & & & & & & Terrigenous/marine & $\begin{array}{l}\text { Marine/terrigenous } \\
\text { Marine (shales) - } \\
\text { Terrigenous (clay- } \\
\text { stones) }\end{array}$ & $\begin{array}{l}\text { Katz } \\
\text { Rullkotter et al. }\end{array}$ \\
\hline & & & & & $\begin{array}{l}\text { Thermogenic } \\
\text { Thermogenic }\end{array}$ & & & $\begin{array}{l}\text { Schaefer and Leythaeuser } \\
\text { Jasper et al. }\end{array}$ \\
\hline & & & & & & & $\begin{array}{l}\text { Marine (shales) } \\
\text { Terrigenous } \\
\text { (claystones) }\end{array}$ & Gilbert \\
\hline & & & & & & & Terrigenous/marine & Nohara et al. \\
\hline
\end{tabular}

a From Meyers, Brassel, and Huc (this volume).

shale in Unit 7 which has values of 1.3 and $2.0 \%$ organic carbon (Meyers, Brassell, and Huc, this volume). The generally low concentrations throughout Units 3 to 7 (Table 1) are similar to the mean organic carbon value of $0.3 \%$ compiled by McIver (1975) from data from DSDP Legs 1 through 31 and reflect a combination of low productivity and poor preservation of organic matter in sediments deposited at Site $\mathbf{5 3 0}$ from Santonian times (84 m.y. ago) through the middle Miocene (10.5 m.y. ago).

Mean atomic $\mathrm{C} / \mathrm{N}$ values of organic matter from the eight lithologic units present in Site 530 sediments and rocks are shown in Figure 2. These values decrease from Unit 1 to Unit 3 , where the mean value is 5.5 , and then increase through Unit 8. Similar patterns of change in $\mathrm{C} / \mathrm{N}$ ratios with sediment age have been reported at Sites $\mathbf{4 4 5}$ and $\mathbf{4 4 6}$ of DSDP Leg 58 in the Philippine Sea and are believed to result from diagenesis of organic matter (Waples and Sloan, 1980). Organic forms of carbon evidently degrade faster than do organic forms of nitrogen in the upper portions of the sediment column (Units 1 to 3) until stable, low concentrations of organic carbon are reached. In deeper and older sediments (Units 4 to 8 ), nitrogen degradation continues, thus causing $\mathrm{C} / \mathrm{N}$ ratios to become larger. The results of this diagenetic effect were noted by Waples and Sloan (1980) in $45 \mathrm{~m}$.y. old deposits from DSDP Leg 58 and can now be seen in these Site 530 materials to late Albian times (96 m.y. ago).

The low amounts of organic matter in Units 3 through 7 preclude kerogen analysis of sediment samples. Based upon the low $\mathrm{C} / \mathrm{N}$ ratios, however, a marine character is assigned to the bulk organic matter in Table 1 . In general, organic matter from marine plankton have $\mathrm{C} / \mathrm{N}$ val-

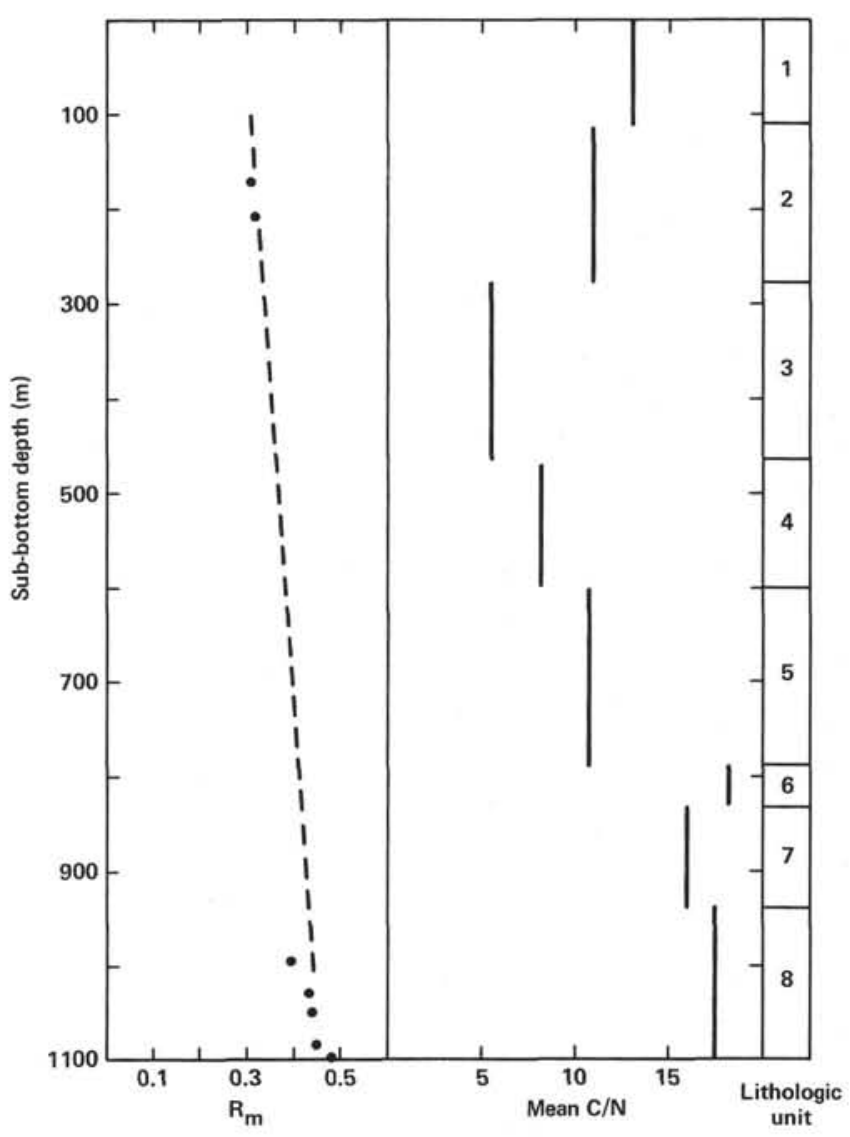

Figure 2. Diagenetic changes with depth in Hole 530A in vitrinite reflectance $\left(\mathrm{R}_{\mathrm{m}}\right)$ and in atomic $\mathrm{C} / \mathrm{N}$ ratios of organic matter. Vitrinite values are from Rullkötter et al. (this volume), and mean $\mathrm{C} / \mathrm{N}$ values for each lithologic unit are calculated from data in Meyers, Brassell, and Huc (this volume). 
ues in the range 5 to 8 (Müller, 1977; Prahl et al., 1980), but the ratios increase in sinking detritus as a result of preferential losses of nitrogenous materials to reach values around 15 in the deeper parts of the oceans (Gordon, 1971). Land plants have higher $\mathrm{C} / \mathrm{N}$ values in the range of 15 to 30 in unaltered material (Müller, 1977). Because of the diagenetic effects on $\mathrm{C} / \mathrm{N}$ ratios evident in Figure 2, the assignment of a marine origin to the organic matter in the sediments of Units 3, 4, and 5 and of mixed marine/terrigenous origin to Units 6 and 7 based on this ratio must be considered tentative.

Gaseous hydrocarbons were analyzed in a sample of Campanian sediment from Unit 5 by Jasper et al. (this volume). The ratio of $C_{1} /\left(C_{2}+C_{3}\right)$ is ca. 20 and is indicative of thermogenic formation (cf. Kvenvolden and Claypool, 1980). In view of the low thermal maturity of most organic matter at Site 530 as indicated by the vitrinite reflectance values of Rullkötter et al. (this volume and Fig. 2), the presence of thermogenic, gaseous hydrocarbons in Unit 5 may result from migration from older and deeper strata into this relatively porous unit.

\section{Unit 8-Early Santonian to Late Albian ${ }^{2}$}

Unit 8 consists of $163 \mathrm{~m}$ of red and green claystones laid down on top of late Albian basalt. Numerous black shale layers are interbedded with the green claystones and have an average thickness of ca. $4 \mathrm{~cm}$. The black shales total only about $8 \%$ of this unit. Much of Unit 8 consists of a mixture of fine-grained turbidites and pelagic sediments. Bioturbation is evident in all of the red and green claystones and in nearly half of the black shale layers. The bottom meter of sedimentary rock appears to be hydrothermally altered or baked (Hay et al., 1982).

The organic-carbon concentrations of samples from Unit 8 are related to their lithologies. As noted in Table 2 , the red and green claystones are organic-carbon-poor and average $0.4 \%$ in concentration. These bioturbated sediments evidently were deposited under oxygenated conditions which did not favor preservation of organic matter. Furthermore, the low organic-carbon values suggest low surface productivity. In contrast to the red and green strata, black shales average $5.4 \%$ organic carbon,

2 Revisions of stratigraphic ages are given in Steinmetz, this volume. and values reach as high as $16.5 \%$ (Meyers, Brassell, and Huc, this volume).

The conditions which resulted in the formation of the black shale layers are problematical. Tissot et al. (1980) and Arthur and Natland (1979) propose that the deep waters of the Angola Basin were anoxic until Turonian times ( 87 to $91 \mathrm{~m} . \mathrm{y}$. ago) because deep circulation was restricted by the Walvis Ridge and Rio Grande Rise to the south and was blocked by the nonrifted connection between Africa and South America to the north. In view of the abundance of bioturbated red claystones of Late Cretaceous age recovered from Angola Basin DSDP sites, however, Thiede and van Andel (1977) and Dean et al. (this volume) conclude that bottom waters generally must have been oxygenated and that anaerobic paleoenvironments existed under an intensified mid-water oxygen minimum that impinged upon the continental slope or shelf of the basin.

The presence of bioturbation in many of the black shale layers at Site 530 (Hay et al., 1982) indicates that these organic-carbon-rich sediments were deposited under bottom waters that contained at least some dissolved oxygen. Preservation of organic matter is not normally good in these conditions unless sufficiently large amounts of material are buried quickly enough to consume the limited oxygen available in sediment pore waters. Such burial requirements would be met by downslope transport by turbidity flow of organic-carbon-rich sediments originally deposited in an intensified oxygen minimum zone under productive surface waters. As stated by Dean et al. (this volume), the essential factor is production of large amounts of organic matter, and the site of this production may have been along the African coastal margin in the proto South Atlantic Ocean.

Geolipid contents of sedimentary rocks in Unit 8 also show some relationships to their lithology. Rullkötter et al. (this volume) analyzed hydrocarbons from eight samples from this unit which ranged in age from Coniacian to Albian. Nearly all their samples show distributions of aliphatic hydrocarbons dominated by longchain terrigenous $n$-alkanes maximizing at $n-C_{31}$. An important exception to this type of pattern is found in Sample 530A-97-3, 105-110 cm, a Cenomanian black shale containing $10.6 \%$ organic carbon. In this sample, aliphatic hydrocarbons contain enhanced contributions of $\mathrm{C}_{17}$ to $\mathrm{C}_{19} n$-alkanes, indicating more aquatic mate-

Table 2. Inferred sources of organic matter in sediments from lithologic subunits of Holes 532A and 532B on the Walvis Ridge. Dominant source appears first. Lithologic information from Hay et al. (1982).

\begin{tabular}{|c|c|c|c|c|c|c|c|c|}
\hline \multirow[b]{2}{*}{ Unit } & \multirow[b]{2}{*}{ Lithology } & \multirow{2}{*}{$\begin{array}{l}\text { Sub-bottom } \\
\text { depth (m) }\end{array}$} & \multirow[b]{2}{*}{ Age $^{a}$} & \multirow{2}{*}{$\begin{array}{l}\text { Mean C } \\
(\%)^{b}\end{array}$} & \multicolumn{3}{|c|}{ Inferred sources of organic matter } & \multirow{2}{*}{$\begin{array}{c}\text { Reference } \\
\text { (this volume) }\end{array}$} \\
\hline & & & & & Interstitial gases & Lipids & Kerogen & \\
\hline $1 \mathrm{a}$ & $\begin{array}{l}\text { Foram-nanno } \\
\text { marl and ooze }\end{array}$ & $0-50$ & Pleistocene & 3.4 & & $\begin{array}{l}\text { Terrigenous/marine } \\
\text { Terrigenous/marine }\end{array}$ & Marine/terrigenous & $\begin{array}{l}\text { Rullkötter et al. } \\
\text { Meyers and Dunham }\end{array}$ \\
\hline & & & & & & & Marine/terrigenous & Meyers, Brassell, and Huc \\
\hline $1 b$ & $\begin{array}{l}\text { Diatom-nanno } \\
\text { marl }\end{array}$ & $50-114$ & $\begin{array}{l}\text { Pleistocene to } \\
\text { Pliocene }\end{array}$ & 3.5 & & Terrigenous/marine & $\begin{array}{l}\text { Marine/terrigenous } \\
\text { Marine/terrigenous }\end{array}$ & $\begin{array}{l}\text { Rullkötter et al. } \\
\text { Meyers, Brassell, and Huc }\end{array}$ \\
\hline 1c & $\begin{array}{l}\text { Nannofossil } \\
\text { marl }\end{array}$ & $114-291$ & $\begin{array}{l}\text { Pliocene to } \\
\text { late Mio- } \\
\text { cene }\end{array}$ & 2.2 & Biogenic & $\begin{array}{l}\text { Terrigenous/marine } \\
\text { Terrigenous/marine }\end{array}$ & $\begin{array}{l}\text { Marine/terrigenous } \\
\text { Marine/terrigenous }\end{array}$ & $\begin{array}{l}\text { Rullkötter et al. } \\
\text { Meyers and Dunham } \\
\text { Meyers, Brassell, and Huc } \\
\text { Schaefer and Leythaeuser }\end{array}$ \\
\hline
\end{tabular}

a Revisions of stratigraphic ages are given in Steinmetz, et al., this volume.

b From Meyers, Brassell, and Huc (this volume). 
rial, and major amounts of pristane and phytane, which may also indicate marine sources. The ratio of pristane to phytane is less than one, suggesting anoxic depositional conditions (Didyk et al., 1978), but greater than one in the remaining samples, which contain between 0.1 and $2.8 \%$ organic carbon. In addition, steroid and triterpenoid saturated hydrocarbons are abundant in the higher molecular weight range of the black shale sample, but not in the organic-carbon-lean claystones.

Aliphatic hydrocarbon contents of adjacent green claystones and black shales are compared by Brassell (this volume) and Meyers, Trull, and Kawka (this volume). In the three such pairs of samples examined, terrigenous components dominate $n$-alkane distributions in both green claystones and black shales, but important amounts of marine $n$-alkanes appear in the black shale hydrocarbons. In an earlier study of an Aptian black shale from DSDP Site 364 in the Angola Basin, Simoneit (1978b) also found alkane distributions to contain both marine and terrigenous source indicators and large contributions of pristane and of phytane. Based upon distributions of aliphatic hydrocarbons, black shales appear to contain a large fraction of marine organic matter whereas the organic matter of green claystones is principally derived from land sources. Comparison of distributions of $n$-alkanoic acids and $n$-alkanols, however, shows that black shales contain more terrigenous material than do adjacent green-colored sediments (Meyers, Trull, and Kawka, this volume). This discrepancy may be explained by better preservation of these geolipid materials in the organic-carbon-rich black shales than in the green claystones. Brassell (this volume) notes an increase in the concentration of the terrigenous hydrocarbon component of black shale relative to the green shale which accompanies the massive addition of marine materials to the black shale. In general, the black shales appear to record periods of enhanced sedimentation of marine geolipids superimposed upon background inputs of terrigenous material observed in the green and red claystones.

Rock-Eval pyrolysis of kerogen from Unit 8 samples shows large variations in organic matter preservation and origins in this unit. Katz (this volume) reports type II and type III kerogens of mixed marine and land origins in a Cenomanian black shale. Organic-carbon-lean samples contain only type III material, indicating either land origin or severe oxidation of marine organic matter. Deroo et al. (this volume) find similar results. Rullkötter et al. (this volume) combine data from Rock-Eval pyrolysis and from maceral microscopy to conclude that in Sample 530A-97-3, 105-110 cm, a black shale, nearly $80 \%$ of the organic matter appears to be of marine origin whereas in a Cenomanian green claystone only a minor fraction of organic matter is marine. This difference agrees with the geolipid data in showing that black shales represent episodes of large inputs of marine organic matter into a normally oxic sedimentary environment. Such inputs evidently accompany turbidite deposition at this site (Dean et al., this volume).

Carbon isotope ratios of organic matter isolated from Cretaceous samples from Site 530 were determined by Nohara et al. (this volume) and are related to the organic carbon content of different lithologies. Green claystones have $\delta^{13} \mathrm{C}$ values averaging $-24.3 \%$, red claystones average $-25.0 \%$, and black shales average $-26.0 \%$. From these isotopically light data, Nohara et al. (this volume) conclude that land-derived material constitutes the major fraction of the organic matter contained in Unit 8 black shales. This conclusion contradicts those summarized in Table 1 which are based upon lipid, pyrolysis, and maceral analyses of these black shale layers. A similar contradiction in source identification from carbon isotope information and from other procedures is found in organic-carbon-rich mid-Cretaceous limestones from DSDP Sites 463,465 , and 466 (Dean et al., 1981). These sites are located on the MidPacific Mountains and on the Hess Rise in the central North Pacific. They are unlikely to have received much terrigenous organic matter due to their location, and the results of Rock Eval pyrolysis and hydrocarbon analysis show a predominance of marine materials. Organic matter in these Pacific samples, however, is isotopically light $\left(\delta^{13} \mathrm{C}\right.$ between -24 to $\left.-29 \%\right)$ and the most lipidrich samples are the lightest $\left(\delta^{13} \mathrm{C}\right.$ between -28 to $-29 \%$ ). Such values, although commonly interpreted to indicate marine organic matter, cannot be accurate source identifiers in the Cretaceous black shales studied by Dean et al. (1981) and Nohara et al. (this volume). Explanation of these exceptionally light carbon isotope values in marine organic matter awaits better understanding of the Cretaceous paleoenvironments during which black shales were deposited, but may reflect selective diagenesis of organic matter.

Organic matter in sediments of Unit 8 is uniformly immature whether in rocks rich or poor in organic carbon content. Pyrolysis temperatures are relatively low (Katz; Deroo et al.; Rullkötter et al., this volume), thermal alteration indices are relatively low (Gilbert, this volume), and vitrinite reflectance values are low (Rullkötter et al., this volume). Although the vitrinite values increase with depth in Hole 530A (Fig. 2), the maximum value found is 0.48 at a sub-bottom depth of $1095 \mathrm{~m}$. The basement heating evident at $1103 \mathrm{~m}$ apparently has not been adequate to affect organic matter only a few meters higher in these sediments. Extractable hydrocarbon concentrations relative to total organic-carbon concentrations are lower in samples of black shale than in adjacent green shales (Brassell; Meyers, Trull, and Kaw$\mathrm{ka}$, this volume), which is further evidence of thermal immaturity.

Despite the evident lack of maturity in these rocks, light hydrocarbons appear to have been produced in small amounts from organic matter contained within them. Analyses by Jasper et al. (this volume) give $C_{1}$ / $\left(C_{2}+C_{3}\right)$ ratios ranging from about 20 to less than one. These values are characteristic of thermogenic hydrocarbons (cf. Kvenvolden and Claypool, 1980). Concentrations of $\mathrm{C}_{2}$ to $\mathrm{C}_{8}$ hydrocarbons, however, are several orders of magnitude below those found in source beds in the main phase of petroleum generation (Schaefer and Leythaeuser, this volume), indicating again the thermal immaturity of Unit 8 material. Although methane 
has clearly moved into organic-carbon-lean green claystones from adjacent black shales rich in organic matter (Jasper et al., this volume), $\mathrm{C}_{3}$ and heavier hydrocarbons have not migrated because of the small amounts that occur in the sediments.

\section{SITE 532-WALVIS RIDGE}

Site 532 is on the eastern part of the Walvis Ridge at a water depth of $1331 \mathrm{~m}$ (Fig. 1) and is about $2 \mathrm{~km}$ from Site 362 of DSDP Leg 40 . Three HPC holes were cored at Site 532, recovering sediments from the water/sediment interface to a maximum sub-bottom depth of $291 \mathrm{~m}$. Although sediment recovery was high, the top meter of each core was disturbed for most cores down to a depth of $100 \mathrm{~m}$ sub-bottom. Below $100 \mathrm{~m}$, the disturbance was less, but parts of cores were gas-cracked (Hay et al., 1982; Site 532 summary, this volume). Samples for organic geochemistry were selected to avoid disturbance and gas-cracking.

One lithologic unit is present at Site 532, and it is divided into three subunits on the basis of relative amounts of carbonaceous, siliceous, and detrital components. These subunits and the results of organic geochemical analyses of samples from them are listed in Table 2.

\section{Subunits 1a, 1b, and 1c-Pleistocene to Late Miocene}

Subunit 1a consists of biogenic marls and oozes made up of varying contributions of nannofossils and foraminifers, composited with small amounts of clay and diatoms. Deposition of this subunit occurred at an average rate of $40 \mathrm{~m} / \mathrm{m}$.y. during Pleistocene times. Subunit $1 \mathrm{~b}$ is more siliceous than subunits $1 \mathrm{a}$ or $1 \mathrm{c}$ and contains up to $40 \%$ diatoms (Hay et al., 1982). This subunit accumulated during the early Pleistocene and late Pliocene at $62 \mathrm{~m} / \mathrm{m}$.y. Subunit $1 \mathrm{c}$ is Pliocene to late Miocene in age and is made up of nannofossil marl in which clay content becomes as high as $60 \%$ in upper Miocene beds. Sedimentation rates average $25 \mathrm{~m} / \mathrm{m}$.y. in subunit $1 \mathrm{c}$.

Throughout Unit 1 sediments, light-dark color cycles a few meters in extent are found. Light-colored regions contain less clay, organic matter, and pyrite and have more carbonate than do the darker layers. The periodicity of these fluctuations is estimated to be 30,000 to 50,000 years (Hay et al., 1982). Bioturbation is commonly extensive throughout this unit and has smeared the light-dark banding, yet the alterations remain especially obvious in Pliocene sediments. Organic carbon concentrations vary between 0.4 and $6.4 \%$ in Pliocene samples from Site 532 and are highest in dark-colored sediments (Meyers, Brassell, and Huc, this volume). The periodicity in clay and organic carbon content is similar to 42,000-year cycles in the intensity of Pleistocene tradewinds inferred from grain-size variations in eolian components of Pacific sediments (Rea, 1982). The corresponding cyclicity in Site 532 sediments may record episodes of stronger winds, enhanced upwelling, and greater biological productivity in this part of the eastern South Atlantic Ocean.
The mean concentrations of organic carbon are relatively high in the three subunits at Site 532 (Table 2). The ranges of values for individual samples are 1.0 to $9.7 \%$ in subunit $1 \mathrm{a}, 1.4$ to $6.4 \%$ in subunit $1 \mathrm{~b}$, and 0.1 to $5.9 \%$ in subunit 1c. As suggested by the mean concentrations in Table 2, older sediments contain the least organic carbon. A marked increase in concentrations occurs at about $280 \mathrm{~m}$ sub-bottom in upper Miocene strata and appears to correlate with a late Miocene beginning of upwelling off Namibia (Diester-Haass and Schrader, 1979; Siesser, 1980). Concentrations of organic carbon and of diatom fossils additionally indicate a maximum in biological productivity around the Pliocene/ Pleistocene boundary (Hay et al., 1982).

Despite the various short-term and long-term fluctuations in concentrations of organic carbon present in sediments from Site 532, the type of organic matter appears to be constant. Atomic $\mathrm{C} / \mathrm{N}$ ratios vary little throughout Unit 1 and average ca. 14 in the three subunits (Meyers, Brassell, and Huc, this volume). Kerogen and lipid analyses also show an unchanging mixture of terrigenous and marine organic matter. Rock-Eval pyrolysis and maceral microscopy classify all kerogens as mixed marine and terrigenous types II-III (Rullkötter et al., this volume) in which amorphous marine macerals are the major component. Aliphatic hydrocarbon distributions are dominated by $\mathrm{C}_{29}, \mathrm{C}_{31}$, and $\mathrm{C}_{33} n$-alkanes characteristic of plant waxes (Meyers and Dunham, Rullkötter et al., this volume). The distributions are very similar in Pleistocene, Pliocene, and late Miocene samples. Furthermore, concentrations of light hydrocarbons, although variable in absolute amount, are constant relative to the organic carbon content of sediment samples (Schaefer and Leythaeuser, this volume).

In view of the evidence of extensive infaunal activity throughout sediments from Site 532, bottom waters must have been generally oxygenated. Pristane/phytane ratios of slightly greater than one are reported by Meyers and Dunham (this volume) and support existence of a weakly oxic depositional environment (Didyk et al., 1978). The presence of alkyl thiophenes, perylene, and pyrite grains (Rullkötter et al., this volume), however, indicates anaerobic conditions (Didyk et al., 1978; Simoneit et al., 1982). These discrepancies in paleoenvironmental indicators may mean that bottom waters fluctuated between oxic and anoxic in response to changes in biotic productivity and/or that strongly anoxic conditions were established quickly beneath the water/sediment boundary. Regardless of how the preservation of organic matter was achieved in these sediments, the presence of the high concentrations of organic carbon in these bioturbated deposits is exceptional and appears to be linked to the high surface productivity associated with the Benguela Current.

Organic matter in Site 532 sediments is uniformly immature. Vitrinite reflectance values fall between 0.24 and 0.31 (Rullkötter et al., this volume), and $n$-alkane distributions have unaltered odd-over-even preferences characteristic of biological origins (Rullkötter et al., Meyers and Dunham, this volume. Interstitial gases, al- 
though sufficiently abundant to cause significant gas cracking, are almost entirely made up of methane (Site 532 summary) and evidently are biogenic. Schaefer and Leythaeuser (this volume) conclude that light hydrocarbons $\left(\mathrm{C}_{2}\right.$ to $\left.\mathrm{C}_{8}\right)$ show little thermal production and no migration.

\section{SUMMARY AND CONCLUSIONS}

1. Sediments deposited from late Miocene to Pleistocene times at Site 532 on the Walvis Ridge and at Site 530 in the Angola Basin contain relatively high concentrations of organic matter which has a mixed marine and terrigenous origin. Marine material is the predominant type, and its abundance is related to the Benguela Current and associated high productivity which began in the late Miocene. Lipid fractions of organic matter contain major contributions of land plant waxes, illustrating significant terrigenous inputs. Similarities in sediments from both sites indicate that they were deposited under productive surface waters and in a common sedimentary environment. Site 530 sediments evidently have been transported downslope from the Walvis Ridge by debris flows and turbidity currents and redeposited in the Angola Basin.

2. Sediments deposited from early Santonian to late Miocene times at Site 530 contain low amounts of highly oxidized marine organic matter, indicating sedimentation under oxygenated conditions and low productivity.

3. Organic-carbon-rich black shales of late Albian to early Santonian age exist at Site 530. They consist of thin turbidite layers interspersed among thick layers of red and green claystones poor in organic matter. They represent brief episodes of very high inputs of marine organic matter superimposed upon a low background of detrital terrigenous organic matter.

4. All sediments rich in organic carbon show high preservation of marine organic matter. Preservation at these sites was enhanced by combinations of rapid burial and poorly oxygenated bottom waters. An extended and intensified oxygen minimum zone impinging the Namibian shelf or slope probably contributed to accumulation of organic-carbon-rich sediments deposited since the late Miocene. Organic matter in Late Cretaceous black shales could have been similarly deposited in shallower locations, relocated to the floor of the Angola Basin by turbidity flow, and preserved by rapid turbiditic burial. Alternatively, short periods of deepwater anoxia may have occurred, but permanently anoxic conditions during Albian to Santonian times are not likely at Site 530 .

5. Formation of organic-carbon-rich sediments at Sites 530 and 532 required high rates of organic-matter production in addition to enhanced preservation.

6. Organic matter is thermally immature throughout these sections, although small amounts of light hydrocarbons have been generated in the black shale layers.

\section{ACKNOWLEDGMENTS}

I thank the authors who sent me copies of their manuscripts and especially Nancy Durham, of the DSDP staff, for her important contributions in helping me prepare this synthesis. I am grateful to K. A.
Kvenovolden and B. R. T. Simoneit for their reviews of this manuscript and their suggestions for improving it.

\section{REFERENCES}

Arthur, M. A., and Natland, J. H., 1979. Carbonaceous sediments in the North and South Atlantic: The role of salinity in stable stratification of Early Cretaceous basins. In Talwani, M., Hay, W., and Ryan, W. B. F., (Eds.), Deep Drilling Results in the Atlantic Ocean: Continental Margins and Paleoenvironment: Washington (Am. Geophys. Union), Maurice Ewing Ser., 3:375-401.

Bishop, J. K. B., Ketten, D. R., and Edmond, J. M., 1978. The chemistry, biology, and vertical flux of particulate matter from the upper $400 \mathrm{~m}$ of the Cape Basin in the southeast Atlantic Ocean. Deep-Sea Res., 25:1121-1161.

Dean, W. E., Claypool, G. E., and Thiede, J., 1981. Origin of organic-carbon-rich mid-Cretaceous limestones, Mid-Pacific Mountains and southern Hess Rise. In Thiede, J., Vallier, T. L., et al., Init. Repts. DSDP, 62: Washington (U.S. Govt. Printing Office), 877-890.

Degens, E. T., and Mopper, K., 1976. Factors controlling the distribution and early diagenesis of organic material in marine sediments. In Riley, J. P., and Chester, R. (Eds.), Chemical Oceanography (Vol. 6): London (Academic Press), 59-113.

Didyk, B. M., Simoneit, B. R. T., Brassell, S. C., and Eglinton, G., 1978. Geochemical indicators of paleoenvironmental conditions of sedimentation. Nature, 272:216-222.

Diester-Haass, L., and Schrader, H. J., 1979. Neogene coastal upwelling history off northwest and southwest Africa. Mar. Geol., 29:39-53.

Gordon, D. C., 1971. Distribution of particulate organic carbon and nitrogen at an oceanic station in the Central Pacific. Deep-Sea Res., 18:1127-1134.

Hay, W. W., Sibuet, J.-C., and Shipboard Scientify Party, 1982. Sedimentation and accumulation of organic carbon in the Angola Basin and on the Walvis Ridge: Preliminary results of Deep Sea Drilling Project Leg 75. Geol. Soc. Am. Bull., 93:1038-1050.

Kvenvolden, K. A., and Claypool, G. E., 1980. Origin of gasolinerange hydrocarbons and their migration by solution in carbon dioxide in Norton Basin, Alaska. Am. Assoc. Petrol. Geol. Bull., 64:1078-1086.

McIver, R., 1975. Hydrocarbon occurrences from JOIDES Deep Sea Drilling Project. Proc. Ninth World Petrol. Congr., pp. 269-280.

Müller, P. J., 1977. C/N ratios in Pacific deep-sea sediments: Effect of inorganic ammonium and organic nitrogen compounds sorbed by clays. Geochim. Cosmochim. Acta, 41:765-776.

Ourisson, G., Albrecht, P., and Rohmer, M., 1979. The hopanoids. Paleochemistry and biochemistry of a group of natural products. Pure Appl. Chem., 51:709-729.

Prahl, F. G., Bennett, J. T., and Carpenter, R., 1980. The early diagenesis of aliphatic hydrocarbons and organic matter in sedimentary particulates from Dabob Bay, Washington. Geochim. Cosmochim. Acta, 44:1967-1976.

Rea, D. K., 1982. Fluctuation in eolian sedimentation during the past five glacial-interglacial cycles: A preliminary examination of data from Deep Sea Drilling Project Hole 503B, eastern equatorial Pacific. In Prell, W. L., Gardner, J. V., et al., Init. Repts. DSDP, 68: Washington (U.S. Govt. Printing Office), 409-419.

Siesser, W. G., 1980. Late Miocene origin of the Benguela upwelling system off northern Namibia. Science, 208:283-285.

Simoneit, B. R. T., 1978a. The organic chemistry of marine sediments. In Riley, J. P., and Chester, R. (Eds.), Chemical Oceanography (Vol. 7): London (Academic Press), 233-311.

, 1978b. Lipid analyses of sediments from Site 364 in the Angola Basin, DSDP Leg 40. In Bolli, H. M., Ryan, W. B. F., et al., Init. Repts. DSDP, 40: Washington (U.S. Govt. Printing Office), 659-662.

Simoneit, B. R. T., Summerhayes, C. P., and Meyers, P. A., 1982. Sources, preservation, and maturation of organic matter in Pliocene and Quaternary sediments of the Gulf of California: A synthesis of organic geochemical studies from Deep Sea Drilling Project Leg 64. In Curray, J. R. Moore, D. G. et al., Init. Repts. DSDP, 64, Pt. 2: Washington (U.S. Govt. Printing Office), 939-951. 
Stevenson, F. J., and Cheng, C. N., 1972. Organic geochemistry of the Argentine Basin sediments: Carbon-nitrogen relationships and Quaternary correlations. Geochim. Cosmochim. Acta, 36:653-671. Thiede, J., and van Andel, Tj. H., 1977. The paleoenvironment of anaerobic sediments in the late Mesozoic South Atlantic Ocean. Earth Planet. Sci. Lett., 33:301-309.

Tissot, B. P., Demaison, G., Masson, P., Deteil, J. R. and Combaz, A. 1980. Paleoenvironment and petroleum potential of the mid-
Cretaceous black shales in the Atlantic basins. Am. Assoc. Petrol. Geol. Bull., 64:2051-2063.

Waples, D. W., and Sloan, J. R., 1980. Carbon and nitrogen diagenesis in deep sea sediments. Geochim. Cosmochim. Acta, 44: 1463-1470.

Date of Initial Receipt: January 31, 1982 